\title{
Chromosome stickiness during meiotic behavior analysis of Passiflora serrato-digitata L. (PASSIFLORACEAE)
}

\author{
Aderência cromossômica durante a análise do comportamento meiótico de Passiflora serrato-digitata L \\ (PASSIFLORACEAE)
}

\author{
Paulo Roberto Peres Kiihl' Andréia Rodrigues Alonso Pereira' ${ }^{\mathrm{I}}$ Sara Mataroli de Godoy \\ Neusa Maria Colauto Stenzel ${ }^{\mathrm{II}}$ Claudicéia Risso-Pascotto ${ }^{\mathrm{I}}$
}

\begin{abstract}
Almost $90 \%$ of species of the genus Passiflora are native to the American continent, with high commercial value due to the fact that some species are used for human food while others have ornamental and medical qualities. Passiflora serrato-digitata is one of the species that integrates the Paraná Agronomic Institute germoplasm bank at its experimental base in Londrina, PR, Brazil. Collected flower buds were fixed in ethanol/acetic acid (3:1 v/v) for 24h, transferred to $70 \%$ alcohol and stored under refrigeration. Slides were prepared by the squashing technique and stained with $1.0 \%$ propionic carmine; they were analyzed under an optic microscope. Irregularities in the chromosome segregation process of $\boldsymbol{P}$. serrato-digitata have been verified by meiotic behavior analysis. These comprised precocious migration to poles in metaphase I and II, non-oriented chromosomes in metaphase plate in metaphase I and II, laggard chromosomes in anaphase I and II towards the formation of micronucleus in telophase I and II, and microspores in tetrads. Chromosome stickiness was another irregularity reported in the Passiflora genus for the first time. These irregularities which also contributed to the formation of monads, dyads and triads, resulted in normal imbalanced $2 n$ and $4 n$ microspores. According to the observed Meiotic Index of $71.83 \%$, this species is not meiotically stable.
\end{abstract}

Key words: microsporogenesis, meiosis, $2 n$ gametes.

RESUMO

Cerca de 90\% das espécies do gênero Passiflora são nativas das Américas, sendo que aproximadamente 200 espécies são nativas do Brasil. Possuem grande importância comercial, pois algumas espécies são utilizadas na alimentação

\begin{abstract}
humana, outras apresentam propriedades medicinais $e$ ornamentais. A espécie Passiflora serrato-digitata faz parte do banco de germoplasma do Instituto Agronômico do Paraná IAPAR, estação experimental de Londrina, PR. Botões florais colhidos foram fixados em etanol/ácido acético $(3: 1 \mathrm{v} / \mathrm{v})$ por 24 horas, transferidos para álcool a 70\% e acondicionado sob refrigeração. As lâminas foram preparadas pela técnica de esmagamento e coradas com carmim propiônico a 1,0\% e observadas ao microscópio óptico. Por meio da análise do comportamento meiótico, foram verificadas irregularidades no processo de segregação dos cromossomos de P. serratodigitata, tais como migração precoce para os pólos em metáfase I e II, cromossomos não orientados na placa equatorial em metáfase I e II, cromossomos retardatários em anáfase I e II, levando a formação de micronúcleo em telófases I e II e micrósporos em tétrades. Outra irregularidade observada foi aderência cromossômica, relatada pela primeira vez no gênero Passiflora, que também pode ter contribuído para a formação de mônades, díades, tríades, as quais foram observadas, resultando em micrósporos normais, desbalanceados, $2 n$ e 4n. De acordo com o Índice Meiótico de 71,83\% observado, essa espécie pode ser classificada como não estável meioticamente.
\end{abstract}

Palavras-chave: microsporogênese, meiose, gametas $2 n$.

\section{INTRODUCTION}

The Passifloraceae family consists of approximately 600 species which are distributed in tropical and subtropical regions; about $90 \%$ belongs

'Biotecnologia Aplicada à Agricultura, Universidade Paranaense (UNIPAR), Av. Huberto Brüning, 360, 87706-560, Paranavaí, PR, Brasil. E-mail: claudiceiarp@unipar.br. *Autor para correspondência.

"Instituto Agronômico do Paraná (IAPAR), Londrina, PR, Brasil. 
to the Passiflora genus, and approximately 200 species are native to Brazil (FERREIRA, 1994). In fact, Brazil and Colombia, the greatest producers of passion fruit, have the greatest species diversity (MELETTI \& MAIA, 1999).

The term maracuja (as the fruit is commonly named in Brazil) is used for all the species of the genus, although only two are commercially cultivated for fruit production. The yellow passion fruit, Passiflora edulis Sims, covering $95 \%$ of Brazilian orchards, is of paramount importance due to the fruit quality, whereas the sweet passion fruit (Passiflora alata Curtis) is becoming popular as an edible fruit (BRAGA et al., 2005). Besides the fruit quality for human intake in juices, sweets, jellies, ice creams and liqueurs, some species are economically important because of their ornamental and medicinal qualities (MELETTI \& MAIA, 1999).

In spite of the great genus variety, few are commercially used. Literature has scanty information on the species under analysis and concentrates only on the morphological features of this fruit. Passiflora serrato-digitata L. is a smooth creeper plant, with a cylindrical stalk and palmate leaves consisting of five to seven lobules; its big oblong flowers have white sepals skimmed with blue on the inside and a greenish white on the outside; petals are rosy blue on both sides. The species has green, sometimes skimmed with red, oval-lance bracts united at the base. The corona filaments are striped in blue, white and purple, turning into pale blue at the apex. Its fruits are round and edible, and reproduction is achieved by seeds and stems. It is native to the tropical and sub-tropical areas of Central America, Guyanas, Brazil, Bolivia and Peru (LIMA, 1999).

SOUZA et al. (2008) state that, despite of its genus extension, the cytogenetics of Passiflora has seldom been studied. In fact, few species have a known chromosome number and even fewer have had their meiotic behavior analyzed. Only the chromosome number of about $30 \%$ of Passiflora species is known (SOARES-SCOTT et al., 2005). In fact, only 40 out of the 200 species native to Brazil, listed by SOUZA et al. (2008), have their chromosome number known. Cytogenetics comprises all analysis related to chromosomes, isolated or in sets, regarding their morphology, organization and function (GUERRA, 1988).

Studies to increase the knowledge of the genetic bases are extremely important for the genetic improvement of the species since detailed information on the meiotic behavior and fertility of pollen grains is a standard tool for intra- and inter-species crossing improvement programs. Further, they also affect evolution and taxonomic investigations (SCHIFINOWITTMANN, 2000). This study reports a detailed study on microsporogenesis of $\boldsymbol{P}$. serrato-digitata species.

\section{MATERIAL AND METHODS}

Seeds of $\boldsymbol{P}$. serrato-digitata species from the Paraná Agronomic Institute germoplasm bank at its experimental base in Londrina, PR, Brazil, were planted in August 2008. The seedlings reached their ideal size for field planting in the beginning of November 2008. Four seedlings were planted on the $3^{\text {rd }}$ November 2008 and were followed by soil correction, conduction system (pruning and fertilization) and weed control (MELETTI \& MAIA, 1999).

Flower buds collected at different stages of the development, from February to April 2009, were fixed in ethanol/acetic acid (3:1 v/v) at room temperature for $24 \mathrm{~h}$, transferred to $70 \%$ alcohol and stored under refrigeration until use. Slides were prepared by squashing technique and stained with $1.0 \%$ propionic carmine; 1.372 microsporocytes were analyzed under an optic microscope. Photomicrographs were made using a digital camera DCE-2 Image Driving Soft Ware, with modifications only in contrast and brightness. Meiotic Index (MI) was calculated according to LÖVE (1951), namely, the number of normal tetrads divided by the total number of tetrads multiplied by 100 .

\section{RESULTS AND DISCUSSION}

The meiotic behavior of $\boldsymbol{P}$. serrato-digitata was analyzed during microsporogenesis and irregularities in the chromosome segregation process were detected. These comprised precocious migrations to poles in metaphase I and II, non-oriented chromosomes on metaphase plate in metaphase I (Figure 1B) and II (Figure 1F), laggard chromosomes in anaphase I (Figure 1C and D) and II towards the formation of micronucleus in telophase I (Figure 1E) and II, and microspores in tetrads. Table 1 shows the frequency of abnormalities.

Although it is being described for the first time in species of the Passiflora genus, an abnormality reported in different plant species has been detected in P. serrato-digitata. Chromosome stickiness is characterized by an intense clustering of chromosomes during any phase of the cell cycle (RAO et al., 1990). Prophase I stage in the species under analysis was normal (Figure 1A) and chromosome stickiness was observed as from metaphase I. Many cells in this phase 


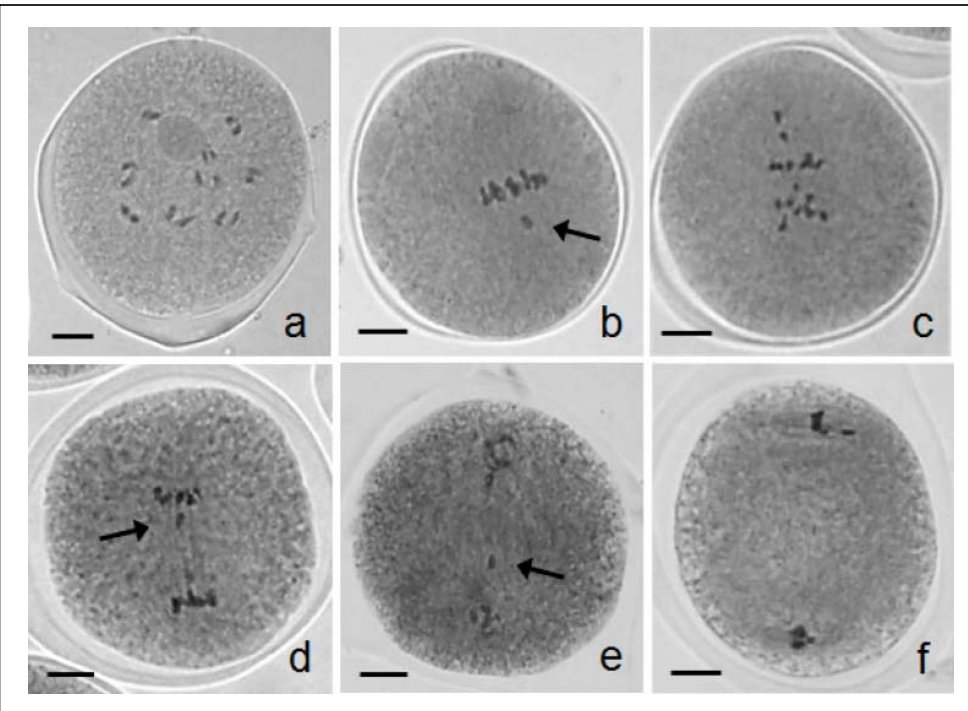

Figure 1 - Aspects of irregular segregation of Passiflora serrato-digitata. a) diakinesis with nine bivalents; b) metaphase I with non-oriented chromosome (arrow); c) anaphase I with early and laggard migration to poles of chromosomes; d) anaphase I with laggards chromosomes (arrow), e) telophase I with micronuclei (arrow); f) metaphase II with precocious migration to the pole. Bar $10 \mu \mathrm{m}$.

Table 1 - Meiotic behaviour in $\boldsymbol{P}$. serrato-digitata.

\begin{tabular}{|c|c|c|c|c|}
\hline Phases & $\begin{array}{c}\text { Number of } \\
\text { analyzed cells }\end{array}$ & $\begin{array}{c}\text { Number of } \\
\text { abnormal cells }\end{array}$ & Abnormalities & Number of cells \\
\hline \multirow{2}{*}{ Metaphase I } & \multirow{2}{*}{142} & \multirow{2}{*}{32} & Non-oriented chromosome & 12 \\
\hline & & & Stickiness & 20 \\
\hline \multirow{2}{*}{ Anaphase I } & \multirow{2}{*}{162} & \multirow{2}{*}{48} & Laggards & 38 \\
\hline & & & Laggards and precocious migration & 10 \\
\hline Telophase I & 190 & 16 & Micronuclei & 16 \\
\hline Prophase II & 176 & 12 & Micronuclei & 12 \\
\hline \multirow{2}{*}{ Metaphase II } & \multirow{2}{*}{216} & \multirow{2}{*}{24} & precocious migration & 02 \\
\hline & & & Stickiness & 22 \\
\hline \multirow{2}{*}{ Anaphase II } & \multirow{2}{*}{130} & \multirow{2}{*}{46} & Laggards & 18 \\
\hline & & & Stickiness & 28 \\
\hline \multirow[t]{4}{*}{ Telophase II } & \multirow[t]{4}{*}{152} & \multirow[t]{4}{*}{16} & Micronuclei & 16 \\
\hline & & & Tetrad with micronuclei & 10 \\
\hline & & & Triad & 11 \\
\hline & & & Triad with microcyte & 18 \\
\hline \multirow[t]{4}{*}{ Tetrad } & \multirow[t]{4}{*}{204} & \multirow[t]{4}{*}{82} & Dyad & 22 \\
\hline & & & Dyad with microcyte & 10 \\
\hline & & & Monad & 07 \\
\hline & & & Monad with microcyte & 04 \\
\hline
\end{tabular}

Ciência Rural, v.41, n.6, jun, 2011. 
showed an uncommon chromosome clustering when they formed the equatorial plate in Metaphase I (Figure 2A, B). However, the separation of chromosome stickiness was irregular when crossing to Anaphase I. In some cases, the non-correct chromosome separation caused bridge and bridge fragmentations (Figure 2C, $\mathrm{D}, \mathrm{E})$. Chromosome fragments became micronuclei in Telophase I (Figure 2F). Stickiness remained in the second division (Figure 2G, H), and the number of pollen mother cells varied according to the phase (Table 1).

Chromosome stickiness has already been reported in plants of several different genera (MENDES-BONATO et al., 2001). BEADLE (1932) reported chromosome stickiness in maize for the first time and attributed such irregularity to a mutation caused by a recessive gene called sticky (st). Recent reports on different species of the genus Brachiaria have been published (MENDES-BONATO et al., 2001; UTSUNOMIYA et al., 2005; RISSO-PASCOTTO et al., 2006; MENDES-BONATO et al., 2007; PAGLIARINI et al., 2008; RISSO-PASCOTTO et al., 2009). They suggest that chromosome stickiness may be under genetic control, or rather, it may be controlled by a single pair of genes, two pairs of genes or by the interaction of several genes which may be recessive or dominant. Stickiness may also have been caused by environmental factors such as X-rays, temperature and soil elements (MENDES-BONATO et al., 2001).

Genetic control may have caused irregularity in the genus Passiflora. In fact, out of the 13 species cultivated under the same environment condition, only P. serrato-digitata showed chromosome stickiness during meiosis. Similar results have been verified by MENDES-BONATO et al. (2001) when they investigated 25 Brachiaria brizantha accesses. Since they actually found irregularity in only one, it is suggested that chromosome stickiness is a phenomenon under genetic control. Furthermore, studies by CAETANO-PEREIRA et al. (1998) showed strong evidence that the presence of Aluminum $\left(\mathrm{Al}^{+3}\right)$ in the soil, besides the genetic factor, may have also caused chromosome stickiness in maize.

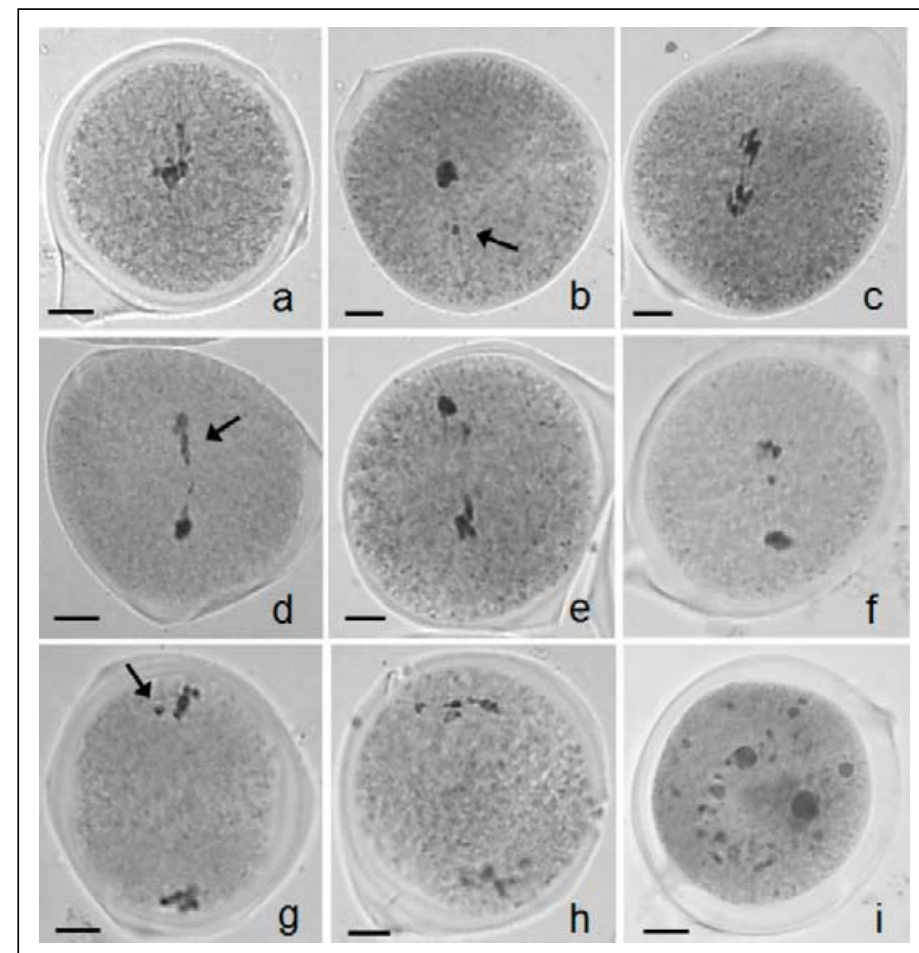

Figure 2 - Chromosome stickiness in meiocytes of Passiflora serratodigitata. a) metaphase I with chromosome stickiness; b) metaphase I with chromosome stickiness and precocious migration (arrow); c) anaphase I with chromosome stickiness; d) telophase I with chromosome stickiness (arrow), e, f) telophase I with micronuclei and gene imbalance; g) metaphase II with precocious migration (arrow) and chromosome stickiness; h) anaphase II with chromosome stickiness; i) monad from the absence of cytokinesis. Bar $10 \mu \mathrm{m}$. 
According to RAO et al. (1990), chromosome stickiness is a cytological phenomenon which is not completely understood even though it has been reported for a long time. Although several factors have been suggested as the cause of chromosome stickiness, the primary cause and biochemical base of this abnormality is largely unknown (MENDES-BONATO et al. (2007). GAULDEN (1987) hypothesizes that chromosome stickiness may be caused by a failure or a bad functioning in one or two types of non-histonic chromosome proteins.

DOWD et al. (1986) classifies stickiness from moderate to severe, according to the number of chromosomes involved in the genome. According to his classification, stickiness investigated in the current study is moderate as, during anaphase, the presence of bridges, which broke down at the end of the anaphase with the subsequent fragmentation and formation of micronuclei in telophase, has been verified. DOWD et al. (1986) state that the irregularity is generally associated with chromosome breakage and acentric fragments of different sizes, which may remain in the cytoplasm as micronuclei.
Micronuclei have been observed in 4.19\% of the analyzed microspores (Figure 3G). In certain cases, micronuclei have been deleted by an extra cytokinesis and produced small microspores and microcytes, amounting to $7.18 \%$ in all. Microspores $2 \mathrm{n}$ and $4 \mathrm{n}($ Figure $3 \mathrm{H}, \mathrm{I})$ have also been found in $3.60 \%$ and $1.20 \%$, respectively. Failure in the cytokinesis process causes the formation of non-reduced $2 \mathrm{n}$ and $4 n$ gametes. BROWN \& LEMMON (1992) report that cytokinesis is the cytoplasm cleavage which follows a pattern determined by the position and the number of nuclei. Since cytokinesis in the genus Passiflora is of the simultaneous type, that is, it occurs at the end of Telophase II, chromosome stickiness verified during the meiosis phases that precede cytoplasm cleavage may have caused failure in the cytokinesis process, forming triads, dyads and monads (Figure 3B-F). Since cleavage is directly related to the nucleus position and number, micronuclei may lead to cytokinesis, with the formation of microcytes in tetrads, triads, dyads and monads (Figure 3A, B, D, F). Pollen grains produced by cells with chromosome stickiness are generally inviable. Fertilization is jeopardized due to the genetic

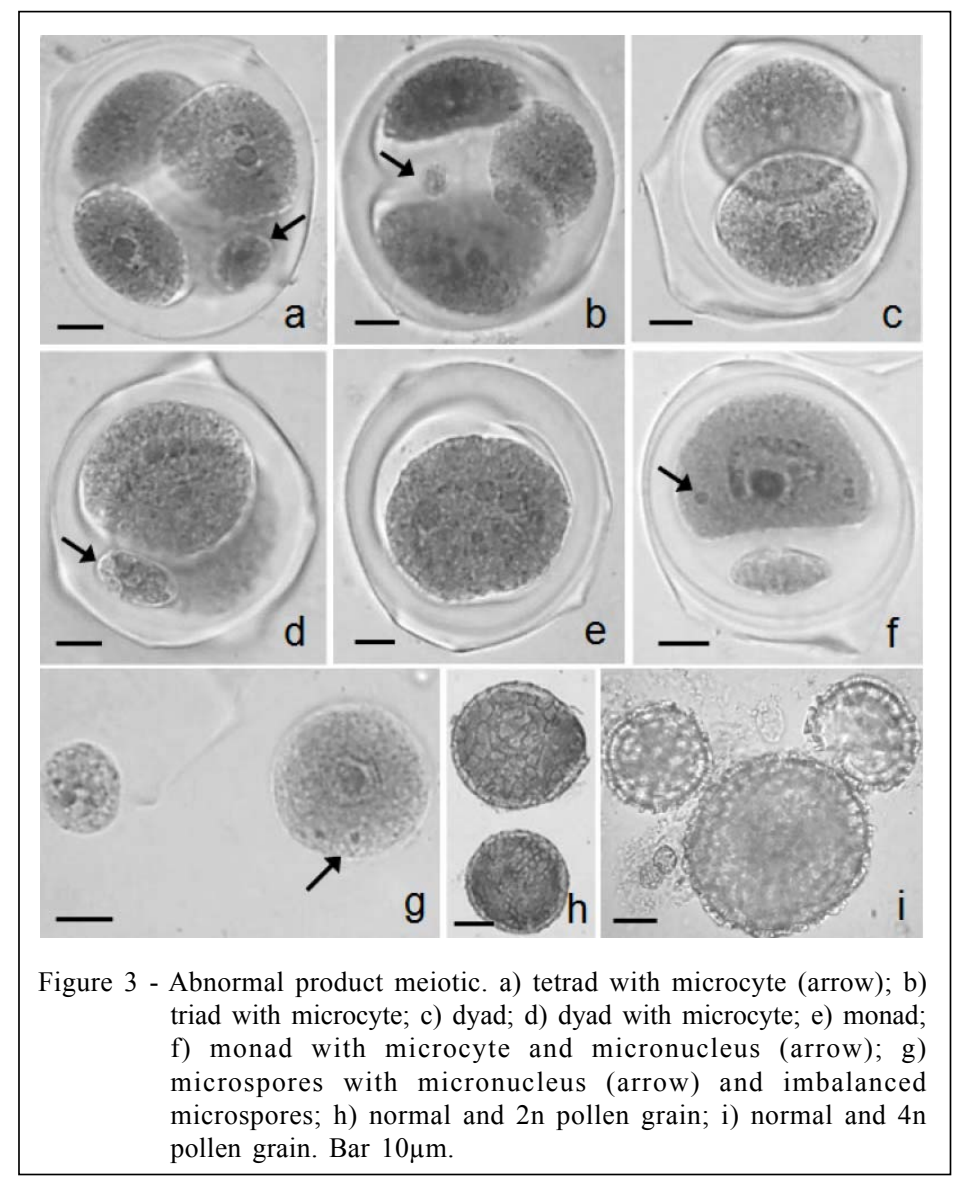

Ciência Rural, v.41, n.6, jun, 2011. 
imbalance caused by the chromosome irregular segregation (CAETANO-PEREIRA et al., 1998). Although fertility tests of pollen grains have not been carried out in this study, $83.83 \%$ were normal when microspores were analyzed at the end of meiosis.

According to LÖVE (1951), the Meiotic Index (MI) is a complement for the meiotic analysis and an indicator of meiotic regularity. Plants with MI higher than or equal to $90 \%$ are cytologically stable. Since MI for P. serrato-digitata was $71.83 \%$, the species is not meiotically stable.

Since gamete fertility depends on meiotic normality, the fertility of the male gametes of species of genus Passiflora is an important factor. This is due to the fact that seed number, fruit size and pulp quantity depend on the number of viable pollen adherent to the stigma (BRAGA et al., 2005).

\section{CONCLUSION}

P. serrato-digitata species presented some irregularities during meiotic behavior analysis related to the chromosome segregation process. Chromosome stickiness was another irregularity reported for the first time in the Passiflora genus. These irregularities, which also contributed towards the formation of monads, dyads and triads, resulted in normal imbalanced $2 \mathrm{n}$ and $4 \mathrm{n}$ microspores. According to the observed MI of $71.83 \%$ in $\boldsymbol{P}$. serrato-digitata, this species is not meiotically stable.

\section{REFERENCES}

BRAGA, M.F. et al. Maracujá-doce: melhoramento genético e germoplasma. In: FALEIRO, F.G. et al. Maracujá: germoplasma e melhoramento. Planaltina, DF: Embrapa Cerrados, 2005. 677p.

BEADLE, G.W. A gene in Zea mays for failure of citokinesis during meiosis. Cytologia, v.3, p.142-155, 1932.

BROWN, R.C.; LEMON, B.E. Cytoplasmic domain: a model for spatial of cytokinesis in reproductive cells of plants. EMSA Bull, v.22, p.48-53, 1992.

CAETANO-PEREIRA, C.M. et al. Syncytes, abnormal cytokinesis and spindle irregularities in maize microsporogenesis. Maydica, v.43, p.235-242, 1998.

DOWD, M.A. et al. Formaldehyde-induced acentric chromosome fragments and chromosome stickiness in Chortophaga neuroblasts. Mutagenesis, v.8, p.401-411, 1986.

FERREIRA, F.R. Germoplasma de Passiflora no Brasil. In: SÃO JOSE, A.R. Maracujá: produção e mercado. Vitória da Conquista: UESB, 1994. p.24-26.

GAULDEN, M.E. Hypothesis: some mutagens directly alter specific chromosomal proteins (DNA topoisomerase II and peripheral proteins) to produce chromosome stickiness, which causes chromosome aberrations. Mutagenesis, v.2, p.357$365,1987$.
GUERRA, M. Mitotic and meiotic analysis of a pericentric inversion associated with a tanden duplication in Eleutherine bulbosa. Chromosoma, v.1, p.80-87, 1988.

LIMA, A.A. O cultivo do maracujá. Cruz das Almas, BA. Embrapa mandioca e Fruticultura, v.35, p.130, 1999.

LÖVE, R.M. Varietal differences in meiotic chromosomes behavior of Brazilian wheat. Agronomy Journal, v.43, p.7276,1951 .

MELETTI, L.M.M.; MAIA, M.L. Maracujá: produção e comercialização. Campinas: Instituto Agronômico, 1999. v.181, 64p. (Boletim Técnico).

MENDES-BONATO, A.B. et al. A severe case of chromosome stickiness in pollen mother cells of Brachiaria brizantha (Hochst) Stapf (Gramineae). Cytologia, v.66, p.287-291, 2001.

MENDES-BONATO, A.B. et al. Meiotic arrest compromises pollen fertility in an interspecific hybrid between Brachiaria ruziziensis x Brachiaria decumbens (Poaceae: paniceae). Brazilian archieves of biology and Technology, v.50, p.831-837, 2007. Available from: <http://www.scielo.br/pdf/ babt/v50n5/a11v50n5.pdf $>$. Accessed: Jan. 27, 2010. doi: $10.1590 / \mathrm{S} 1516-89132007000500011$.

PAGLIARINI, M.S. et al. Analysis of meiotic behavior in selecting potential genitors among diploid and artificially induced tetraploid accessions of Brachiaria ruziziensis (Poaceae). Euphytica, v.164, p.181-187, 2008.

RAO, P.N. et al. Behavior of a sticky desynaptic mutant in pearl millet. Genetica, v.81, p.221-227, 1990.

RISSO-PASCOTTO, C. et al. Microsporogenesis in Brachiaria dictyoneura (Fig. \& De Not.) Stapf (Poaceae: Paniceae). Genetics and Molecular Research, v.5, p.837-845, 2006. Available from: <http://www.funpecrp.com.br/gmr/year2006/ vol4-5/pdf/gmr0242.pdf>. Accessed: Jan. 29, 2010.

RISSO-PASCOTTO, C. et al. Microsporogenesis in Brachiaria bovonei (Chiov.) Robyns and B. subulifolia (Poaceae). Scientia Agricola, v.66, p.691-696, 2009. Available from: $<$ http://www.scielo.br/pdf/sa/v66n5/15.pdf $>$. Accessed: Jan. 12, 2010. doi: 10.1590/S0103-90162009000500015.

SCHIFINO-WITTMANN, M.T. The cytogenetics and evolution of forage legumes from Rio Grande do Sul: a rewiew. Genetics and Molecular Biology, v.23, p.989-995, 2000. Available from: <http:/www.scielo.br/pdf/gmb/v23n4/6261.pdf >. Accessed: Jan. 12, 2010. doi: 10.1590/S1415-47572000000400044.

SOARES-SCOTT, M.D. et al. Citogenética clássica e molecular em Passifloras. In: FALEIRO, F.G. et al. Maracujá: germoplasma e melhoramento. Planaltina, DF: Embrapa Cerrados, 2005. 677p.

SOUZA, M.M. et al. Cytogenetic studies in some species of Passiflora L. (Passifloraceae): a review emphasizing brazilian species. Brazilian archieves of biology and Technology, v.51, p.247-258, 2008. Available from: <http://www.scielo.br/ $\mathrm{pdf} / \mathrm{babt} / \mathrm{v} 51 \mathrm{n} 2 / \mathrm{a} 03 \mathrm{v} 51 \mathrm{n} 2 . \mathrm{pdf}>$. Accessed: Jan. 12, 2010 . doi: $10.1590 / \mathrm{S} 1516-89132008000200003$.

UTSUNOMIYA, K.S. et al. Microsporogenesis in tetraploid accessions of Brachiaria nigropedata (Ficalho \& Hiern) Stapf (Gramineae). Biocell, v.29, p.295-30, 2005. Available from: $<$ http://www.cricyt.edu.ar/biocell/vol/pdf/29_3/07.pdf $>$. Accessed: Jan. 12, 2010. ISSN 1667-5746. 